\title{
Diversity and Biocontrol Potential of Cultivable Endophytic Bacteria Associated with Halophytes from the West Aral Sea Basin
}

\author{
Lei Gao ${ }^{1,2}$, Jimbiao Ma ${ }^{1}(\mathbb{D})$, Yonghong Liu ${ }^{1}(\mathbb{D})$, Yin Huang ${ }^{1}$, Osama Abdalla Abdelshafy Mohamad ${ }^{1}(\mathbb{D}$, \\ Hongchen Jiang 1,3 ${ }^{\mathbb{D}}$, Dilfuza Egamberdieva ${ }^{4,5} \mathbb{D}$, Wenjun $\mathrm{Li}^{1,6, * \mathbb{D}}$ and $\mathrm{Li} \mathrm{Li}{ }^{1, *}$
}

1 State Key Laboratory of Desert and Oasis Ecology, Xinjiang Institute of Ecology and Geography, Chinese Academy of Sciences, Urumqi 830011, China; gaolei19@mails.ucas.ac.cn (L.G.); majinbiao@ms.xjb.ac.cn (J.M.); liuyh@ms.xjb.ac.cn (Y.L.); yinhuang0929@163.com (Y.H.); osama@aru.edu.eg (O.A.A.M.); jiangh@cug.edu.cn (H.J.)

2 College of Resources and Environment, University of Chinese Academy of Sciences, Beijing 100049, China

3 State Key Laboratory of Biogeology and Environmental Geology, China University of Geosciences, Wuhan 430074, China

4 Faculty of Biology, National University of Uzbekistan, Tashkent 100174, Uzbekistan; egamberdieva@yahoo.com

5 Leibniz Centre for Agricultural Landscape Research (ZALF), 15374 Müncheberg, Germany

6 State Key Laboratory of Biocontrol, Guangdong Provincial Key Laboratory of Plant Resources, School of Life Sciences, Sun Yat-Sen University, Guangzhou 510275, China

* Correspondence: liact@hotmail.com (W.L.); lili.bobo@outlook.com (L.L.)

check for updates

Citation: Gao, L.; Ma, J.; Liu, Y.; Huang, Y.; Mohamad, O.A.A.; Jiang, H.; Egamberdieva, D.; Li, W.; Li, L. Diversity and Biocontrol Potential of Cultivable Endophytic Bacteria Associated with Halophytes from the West Aral Sea Basin. Microorganisms 2021, 9, 1448. https://doi.org/ 10.3390/microorganisms 9071448

Academic Editor: Renato Fani

Received: 3 June 2021

Accepted: 1 July 2021

Published: 6 July 2021

Publisher's Note: MDPI stays neutral with regard to jurisdictional claims in published maps and institutional affiliations.

Copyright: (c) 2021 by the authors. Licensee MDPI, Basel, Switzerland. This article is an open access article distributed under the terms and conditions of the Creative Commons Attribution (CC BY) license (https:/ / creativecommons.org/licenses/by/ $4.0 /)$.

\begin{abstract}
Endophytes associated with halophytes may contribute to the host's adaptation to adverse environmental conditions through improving their stress tolerance and protecting them from various soil-borne pathogens. In this study, the diversity and antifungal activity of endophytic bacteria associated with halophytic samples growing on the shore of the western Aral Sea in Uzbekistan were investigated. The endophytic bacteria were isolated from the nine halophytic samples by using the culture-dependent method and identified according to their 16S rRNA gene sequences. The screening of endophytic bacterial isolates with the ability to inhibit pathogenic fungi was completed by the plate confrontation method. A total of 289 endophytic bacterial isolates were isolated from the nine halophytes, and they belong to Firmicutes, Actinobacteria, and Proteobacteria. The predominant genera of the isolated endophytic bacteria were Bacillus, Staphylococcus, and Streptomyces, accounting for $38.5 \%, 24.7 \%$, and $12.5 \%$ of the total number of isolates, respectively. The comparative analysis indicated that the isolation effect was better for the sample S8, with the highest diversity and richness indices. The diversity index of the sample S7 was the lowest, while the richness index of samples S5 and S6 was the lowest. By comparing the isolation effect of 12 different media, it was found that the M7 medium had the best performance for isolating endophytic bacteria associated with halophytes in the western Aral Sea Basin. In addition, the results showed that only a few isolates have the ability to produce ex-enzymes, and eight and four endophytic bacterial isolates exhibited significant inhibition to the growth of Valsa mali and Verticillium dahlia, respectively. The results of this study indicated that halophytes are an important source for the selection of microbes that may protect plant from soil-borne pathogens.
\end{abstract}

Keywords: endophytes; halophytes; diversity; antifungal activity; Aral Sea

\section{Introduction}

In the past about 50 years, due to the frequent interruption of human activities and the increasing irrigation water of agriculture, the water area of the Aral Sea has been decreasing, and the salinity of the Aral sea has been rising, which has given rise to a series of ecological and environmental problems [1-3]. The soil salinization is problematic in 
many parts of the world and causes severe food crises through reducing agricultural lands for crop production [4]. Previous reports indicated that salinity increases the susceptibility of plants towards various phytopathogens and is considered as a major factor affecting crop growth and cereal yield [5-9]. Since chemical control of plant diseases has negative effects on environment [10], biological control agents based on microbes is one of the alternative ecological safe approaches to protect plants from pathogens [11,12].

Halophytes have evolved several strategies to withstand abiotic and biotic stresses through their associated microbiome [4,13]. Endophytes are a group of organisms (such as bacteria or fungi) living within a plant, being found in almost all plants worldwide [14]. Endophytes play a very vital role in the improvement of plant growth and development, the phytoremediation of contaminated environments by production of a variety of secondary metabolites with special functional activities, and the plant resistance to plant diseases caused by pathogenic fungi [15-18]. Therefore studying the endophytic bacterial diversity and their antifungal activity is of great importance in developing biological control agents. In one review related to Streptomyces as efficient colonizers of plant tissues, the author summarized that metabolites like antibiotics and volatile organic compounds may have great potential as excellent agents for controlling various fungal and bacterial phytopathogens [19]. You et al. [20] isolated one endophytic bacteria isolate BZJN1, identified as Bacillus subtilis by physiological experiments, biochemical tests, and molecular identification, and found it can significantly inhibit the growth of Ceratobasidium sp., a group of plant pathogenic fungi. Wang et al. isolated a total of 165 cultivable endophytic bacterial isolates from the Dendrobium, a traditional medicinal plant in China, and 14 endophyte bacterial isolates able to control phytopathogen were detected using the Kirby-Bauer method [21]. Experiments such as that conducted by Bibi (2018) have shown that the endophytic bacteria from seagrass have the characteristics of diversity and wide antagonistic effects on phytopathogen [22].

In this study, we reported the diversity of cultivable endophytic bacteria associated with nine halophytes collected from the western Aral Sea Basin in Uzbekistan and their antifungal activity. The objectives of our study were: (1) to isolate and identify cultivable endophytic bacteria associated with nine halophytes growing in saline soil by using the culture-dependent method and 16S rRNA gene sequencing; (2) to determine the best medium for isolating endophytic bacteria associated with halophytes from the western Aral Sea Basin; (3) to explore the differences of cultivable endophytic bacteria isolated from halophytes in different exposed zones of the western Aral Sea Basin; and (4) to evaluate the antifungal activities of the isolated endophytic bacterial isolates.

\section{Materials and Methods}

\subsection{Sample Collection and Site Description}

According to the follow-up survey records of the Institute of Natural Sciences, Academy of Karakalpakstan, from the 1970s to 2018, owing to the shrinking water area, the western Aral Sea has formed a huge exposed zone, which extended to about $1500 \mathrm{~m}$ from the shoreline to the far shore [23]. We defined the original exposed zone as E1970S, followed by E1980S, E1990S, E2000S, and E2009S, which indicated that these soil bands were exposed in about the 1970s, 1980s, 1990s, 2000s, and 2009 respectively. Furthermore, we also collected halophytic samples from ODZ, which means the non-exposed zone or the outside of the degradation zone, to explore the endophytic bacterial diversity completely.

Nine halophyte samples labeled from S1 to S9 respectively were collected in 2018 from the western Aral Sea in Uzbekistan and placed in aseptic bags, which placed ice straightway and transported back to our lab (Table 1). These nine halophyte samples belong to six halophytic species, which are widely distributed on the shore of the Western Aral Sea. This indicated that these halophytes are the dominant species in the local area. Therefore, these dominant plants growing on the shore of the Western Aral Sea were selected to investigate endophytic bacterial diversity and community structure (Supplementary Table S1 and Table 1). 
Table 1. Samples information.

\begin{tabular}{|c|c|c|c|c|}
\hline Sample Num. & Sample Name & Exposed Zone & $\begin{array}{l}\text { The Distance to } \\
\text { the Shoreline (m) }\end{array}$ & Location \\
\hline S1 & Chenopodium album $\mathrm{L}$. & E2009S & $\sim 200$ & \multirow{9}{*}{$\begin{array}{c}44^{\circ} 29^{\prime} 50.42^{\prime \prime} \mathrm{N} \sim \\
44^{\circ} 29^{\prime} 50.4233^{\prime \prime} \mathrm{N}, \\
58^{\circ} 12^{\prime} 43.80^{\prime \prime} \mathrm{E} \sim \\
58^{\circ} 13^{\prime} 42.31^{\prime \prime} \mathrm{E}\end{array}$} \\
\hline $\mathrm{S} 2$ & Chenopodium album $\mathrm{L}$. & E2000S & $\sim 300$ & \\
\hline S3 & Chenopodium album $\mathrm{L}$. & E1990S & $\sim 700$ & \\
\hline $\mathrm{S} 4$ & Salsola collina Pall. & E1990S & $\sim 700$ & \\
\hline S5 & Haloxylon ammodendron (C. A. Mey.) Bunge & E1980S & $\sim 1000$ & \\
\hline S6 & Haloxylon ammodendron (C. A. Mey.) Bunge & E1970S & $\sim 1200$ & \\
\hline S7 & Alhagi sparsifolia Shap. & E1970S & $\sim 1200$ & \\
\hline S8 & Anabasis eriopoda (Schrenk) Benth. ex Volkens & ODZ & $>1500$ & \\
\hline S9 & Anabasis truncata (Schrenk) Bunge & ODZ & $>1500$ & \\
\hline
\end{tabular}

\subsection{Sterilization of Plant Materials}

All the collected plants were washed under running tap water to remove the soil attached to the root and dust on the plant surface. The plants were sterilized with $75 \%$ ethanol for $1 \mathrm{~min}$ and subsequently with $5 \% \mathrm{NaClO}$ for $8 \mathrm{~min}$ and were rinsed five times in sterile distilled water [24]. To check the sterility of the surface of plants after surface sterilization of plant materials, we spread $100 \mu \mathrm{L}$ of the last rinse $\mathrm{ddH}_{2} \mathrm{O}$ on the TSA plate, and found the absence of any colonies after 3-day incubation, which confirmed that sterilization was thorough. The sterile plants were cut into $1-2 \mathrm{~cm}$ pieces with a sterile scalpel and dried in the horizontal flow clean bench. Finally, all of the samples were crushed by a sterile masher and stored at $-20^{\circ} \mathrm{C}$.

\subsection{Isolation of Endophytic Bacteria}

The plant sample $(1 \mathrm{~g})$ was ground using a sterile mortar and transferred into a conical flask with $9 \mathrm{~mL}$ of sterile water and shaken for $100 \mathrm{rpm}, 30 \mathrm{~min}$ using a Shaken Incubator (Shanghai Tensuc Lab Instruments Manufacturing Co., Ltd., Shanghai, China). About $100 \mu \mathrm{L}$ dilutions $\left(10^{-2}-10^{-4}\right)$ were spread on the isolated plates (Table 2$)$ and the plates were incubated for 15 days at $30^{\circ} \mathrm{C}$. After 15 days, colonies with different shapes and colors were picked and carefully transferred by streaking on Tryptic Soy Agar plates (TSA) and incubated for the next 3 days to check the purity of the isolates. Visually homological colonies in sizes, shapes, and colors were removed from duplicate isolates and reduced the number of isolates to be sequenced.

Table 2. Medium component.

\begin{tabular}{|c|c|}
\hline Medium Num. & Medium Component (1 L), Agar 15 g, pH 7.2 \\
\hline M1 & Yeast extract $0.25 \mathrm{~g}, \mathrm{~K}_{2} \mathrm{HPO}_{4} 0.5 \mathrm{~g}, \mathrm{NaCl} 30 \mathrm{~g}$ \\
\hline M2 & 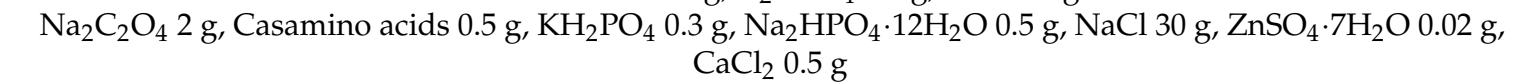 \\
\hline M3 & $\begin{array}{c}\text { Glycerol } 10 \mathrm{~g} \text {, L-Asparagine } 1 \mathrm{~g}, \mathrm{NaCl} 30 \mathrm{~g}, \mathrm{~K}_{2} \mathrm{HPO}_{4} 1 \mathrm{~g}, \mathrm{FeSO}_{4} \cdot 7 \mathrm{H}_{2} \mathrm{O} 0.001 \mathrm{~g}, \mathrm{MnSO}_{4} \cdot \mathrm{H}_{2} \mathrm{O} 0.001 \mathrm{~g} \\
\mathrm{ZnSO}_{4} \cdot 7 \mathrm{H}_{2} \mathrm{O} 0.001 \mathrm{~g}, \mathrm{CuSO}_{4} \cdot 5 \mathrm{H}_{2} \mathrm{O} 0.001 \mathrm{~g}\end{array}$ \\
\hline M4 & $\mathrm{Na}_{2} \mathrm{SeO}_{3} 1 \mathrm{~g}$, L-Asparagine $1 \mathrm{~g}, \mathrm{MgSO}_{4} \cdot 7 \mathrm{H}_{2} \mathrm{O} 0.5 \mathrm{~g}, \mathrm{FeSO}_{4} \cdot 7 \mathrm{H}_{2} \mathrm{O} 0.05 \mathrm{~g}, \mathrm{NaCl} 30 \mathrm{~g}, \mathrm{CaCl}_{2} 0.5 \mathrm{~g}, \mathrm{KH}_{2} \mathrm{PO}_{4} 0.2 \mathrm{~g}$, \\
\hline M5 & Sodium propionate $2 \mathrm{~g}$, L-Asparagine $1 \mathrm{~g},\left(\mathrm{NH}_{4}\right)_{2} \mathrm{SO}_{4} 0.1 \mathrm{~g}, \mathrm{KCl} 0.1 \mathrm{~g}, \mathrm{MgSO}_{4} \cdot 7 \mathrm{H}_{2} \mathrm{O} 30 \mathrm{~g}, \mathrm{FeSO}_{4} \cdot 7 \mathrm{H}_{2} \mathrm{O} 0.05 \mathrm{~g}$ \\
\hline M6 & Chitin $2 \mathrm{~g}, \mathrm{NaCl} 30 \mathrm{~g}, \mathrm{~K}_{2} \mathrm{HPO}_{4} 0.7 \mathrm{~g}, \mathrm{KH}_{2} \mathrm{PO}_{4} 0.3 \mathrm{~g}, \mathrm{MgSO}_{4} \cdot 7 \mathrm{H}_{2} \mathrm{O} 0.5 \mathrm{~g}, \mathrm{MnCl}_{2} 0.001 \mathrm{~g}$ \\
\hline M7 & Tryptone $15 \mathrm{~g}$, Soybean peptone $5 \mathrm{~g}, \mathrm{NaCl} 30 \mathrm{~g}$ \\
\hline M8 & Citric Acid $0.12 \mathrm{~g}$, Ferric citrate $0.12 \mathrm{~g}, \mathrm{NaCl} 30 \mathrm{~g}, \mathrm{NaNO}_{3} 0.5 \mathrm{~g}, \mathrm{~K}_{2} \mathrm{HPO}_{4} 0.4 \mathrm{~g}, \mathrm{MgSO}_{4} \cdot 7 \mathrm{H}_{2} \mathrm{O} 0.2 \mathrm{~g}, \mathrm{CaCl}_{2} 0.5 \mathrm{~g}$ \\
\hline M9 & $\begin{array}{c}\text { Cellulose microcrystalline } 2.5 \mathrm{~g} \text {, Proline } 1 \mathrm{~g}, \mathrm{NaCl} 30 \mathrm{~g}, \mathrm{KNO}_{3} 0.25 \mathrm{~g}, \mathrm{MgSO}_{4} \cdot 7 \mathrm{H}_{2} \mathrm{O} 0.2 \mathrm{~g}, \mathrm{~K}_{2} \mathrm{HPO}_{4} 0.2 \mathrm{~g}, \mathrm{CaCl}_{2} \\
0.5 \mathrm{~g}, \mathrm{FeSO}_{4} \cdot 7 \mathrm{H}_{2} \mathrm{O} 0.01 \mathrm{~g}\end{array}$ \\
\hline M10 & Sodium propionate $2 \mathrm{~g}$, Arginine $1 \mathrm{~g}, \mathrm{NaCl} 30 \mathrm{~g}, \mathrm{MgSO}_{4} \cdot 7 \mathrm{H}_{2} \mathrm{O} 1 \mathrm{~g}, \mathrm{KH}_{2} \mathrm{PO}_{4} 0.1 \mathrm{~g}, \mathrm{FeSO}_{4} \cdot 7 \mathrm{H}_{2} \mathrm{O} 0.05 \mathrm{~g}$ \\
\hline M11 & Starch $20 \mathrm{~g}, \mathrm{KNO}_{3} 1 \mathrm{~g}, \mathrm{NaCl} 0.5 \mathrm{~g}, \mathrm{MgSO}_{4} \cdot 7 \mathrm{H}_{2} \mathrm{O} 0.5 \mathrm{~g}, \mathrm{~K}_{2} \mathrm{HPO}_{4} 0.5 \mathrm{~g}, \mathrm{FeSO}_{4} \cdot 7 \mathrm{H}_{2} \mathrm{O} 0.01 \mathrm{~g}$ \\
\hline M12 & 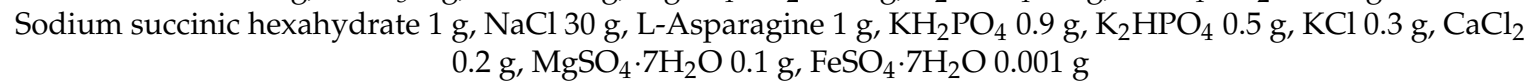 \\
\hline
\end{tabular}




\subsection{DNA Extraction, PCR Amplification and $16 S$ rRNA Gene Sequencing}

The chelex-100 method was used for DNA extraction. The small parts of the colonies were transferred into PCR tubes with $200 \mu \mathrm{L}$ 5\% chelex-100 and were mixed with a Biosan B-1 Vortex for $10 \mathrm{~s}$. The tubes were incubated at $99{ }^{\circ} \mathrm{C}$ for $30 \mathrm{~min}$ in a PCR instrument (C1000 Touch $^{\mathrm{TM}}$ Thermal Cycler, BioRad Laboratories, Hercules, CA, USA) and centrifuged at $12,000 \times g$ for $10 \mathrm{~min}$. DNA-containing supernatant was stored at $-20{ }^{\circ} \mathrm{C}$ for polymerase chain reaction (PCR). The $16 \mathrm{~S}$ rRNA genes were amplified via PCR using the following primers: 27F (5'-GAGTTTGATCCTGGCTCAG-3') and 1492R (5'GAAAGGAGGTGATCCAGCC-3') (Biomed, Beijing, China) [25]. Extracted DNA was used as a template for $16 \mathrm{~S}$ rRNA gene amplification. Each $50 \mu \mathrm{L}$ of reaction mixture contained $4 \mu \mathrm{L}$ (20-30 ng) template DNA, $25 \mu \mathrm{L} 2 \times$ Taq MasterMix (Coolaber, Beijing, China), $2 \mu \mathrm{L} 27 \mathrm{~F}$, $2 \mu \mathrm{L}$ 1492R, and $17 \mu \mathrm{L}$ DNase/RNase-Free Deionized Water (TIANGEN BIOTECH (BEIJING) CO., Ltd., Beijing, China). The PCR was performed using a C1000 Touch ${ }^{\mathrm{TM}}$ Thermal Cycler (Bio-Rad Laboratories, USA). The PCR program was as follows: pre-denaturation at $94{ }^{\circ} \mathrm{C}$ for $4 \mathrm{~min}$, followed by 35 cycles of denaturation for $30 \mathrm{~s}$ at $94{ }^{\circ} \mathrm{C}$, annealing for $30 \mathrm{~s}$ at $55^{\circ} \mathrm{C}$ and extension for $1.5 \mathrm{~min}$ at $72{ }^{\circ} \mathrm{C}$, followed by the final step for $7 \mathrm{~min}$ at $72{ }^{\circ} \mathrm{C}$. The PCR-amplified products were examined by electrophoresis in a $1.2 \%$ agarose gel containing GoldviewTM. The PCR products were purified and sequenced in Sangon Biotech, Shanghai, China. Received merged data were compared with those registered in the EZBioCloud database (https:/ / www.ezbiocloud.net/, accessed on 11 December 2020) using a basic online alignment search tool (16S-based ID).

\subsection{Accession Numbers}

The 16S rRNA gene sequences of the endophytic bacteria of nine halophytes were deposited into GenBank under the accession numbers: MW664036-MW664324.

\subsection{Screening of Bacterial Isolates Producing Protease, Lipase, and Cellulose}

Testing the protease activity was determined by growing the isolates on Skim Milk Agar medium. After incubation for 7 days at $30^{\circ} \mathrm{C}$, the positive results were indicated by the formation of a clear halo zone around the bacterial colonies [26]. Cellulose activity was tested by inoculating bacterial isolates onto a medium containing a unique cellulose substrate namely carboxy methyl cellulose sodium salt (CMC-Na) [27]. After 7 days of incubation at $30{ }^{\circ} \mathrm{C}$, all plates were stained with $5 \mathrm{~mL} 0.1 \%$ Congo red solution for $10 \mathrm{~min}$ and then rinsed by using $5 \mathrm{~mL} 1 \mathrm{M} \mathrm{NaCl}$. Positive results were indicated by the formation of a clear or lightly colored zone around the colony. The assay of lipase activity was carried out by using bacterial isolates being scratched on Tween 80 medium [28]. The content of Tween 80 medium was as follows: $10 \mathrm{~mL} / \mathrm{L}$ Tween $80,50 \mathrm{~mL} / \mathrm{L}$ Victoria Blue-suspension, $10 \mathrm{~g} / \mathrm{L}$ peptone, $5 \mathrm{~g} / \mathrm{L} \mathrm{NaCl}, 0.1 \mathrm{~g} / \mathrm{L} \mathrm{CaCl}_{2} \cdot 7 \mathrm{H}_{2} \mathrm{O}$, and $15 \mathrm{~g} / \mathrm{L}$ agar. Bacteria isolates were incubated for 7 days at $30^{\circ} \mathrm{C}$ and the formation of a clear halo was observed indicating the result is positive. The enzyme production capacity was calculated by the formula (three replicates to get the average enzyme production capacity) [29]. E refers to the enzyme production capacity of endophytic bacteria. D1 refers to the diameter of the clear zone and D2 refers to the diameter of the endophytic bacterial isolate.

$$
\mathrm{E}=\frac{\mathrm{D} 1}{\mathrm{D} 2} \times 100
$$

\subsection{Screening of Endophytic Bacterial Isolates for Their Antifungal Activity}

The plate confrontation method was used to screen endophytic bacterial isolates with the ability to inhibit pathogenic fungi. In the experimental group, the pathogenic fungi $(0.5 \mathrm{~cm}$ in diameter) were inoculated in the center of the PDA plate and tested endophytic bacteria were inoculated $2.5 \mathrm{~cm}$ from the center with pathogenic fungi. The plate inoculated with pathogenic fungi and not inoculated with tested endophytic bacteria was regarded as a control group. All of the plates were put in an incubator at $25^{\circ} \mathrm{C}$ for 7 days. After the pathogenic fungi of $\mathrm{CK}$ treatment grew all over the petri dish, the growth diameter of 
the pathogen was measured and the inhibition rate of endophytic bacteria reisolating the pathogen mycelium was calculated according to the formula (three replicates to get the average inhibition rate) [30]. CK refers to the colony diameter of pathogenic fungi in the control group. EXP refers to the colony diameter of pathogenic fungi in the experimental group; $0.5 \mathrm{~cm}$ refers to the colony diameter of pathogenic fungi at the beginning of the inoculation. The pathogens for the antagonistic testing are Valsa mali, Verticillium dahliae, Fusarium oxysporum, and Fusarium solani.

$$
\text { Inhibition rate }=\frac{[(\mathrm{CK}-0.5 \mathrm{~cm})-(\mathrm{EXP}-0.5 \mathrm{~cm})]}{\mathrm{CK}-0.5 \mathrm{~cm}} \times 100
$$

\subsection{Statistical Analysis}

Statistical analyses and visualization of all isolation data were completed by Microsoft Excel 2019 and R (version 4.0.3). The flower diagram was produced with the GENESCLOUD, an online drawing tool for scientific research. The Upset plot was created on the website (https://www.omicstudio.cn/tool/43, accessed on 15 December 2020), a web-based drawing tool for scientific research. Furthermore, we use the LSD test of $\mathrm{R}$ software to examine the significant difference in inhibition rate among endophytic bacterial isolates.

\section{Results}

\subsection{Isolation and Identification of Cultivable Endophytic Bacteria}

A total of 289 endophytic bacteria belonging to 3 phyla, 6 classes, 14 orders, 17 families, and 19 genera were isolated from nine samples (Figure 1A-C; Supplementary Table S2). The isolation results showed that the predominant genera were Bacillus, Staphylococcus, and Streptomyces, accounting for $38.5 \%, 24.7 \%$, and $12.5 \%$ of the total number of isolates, respectively (Figure $1 \mathrm{C}$ ).

A

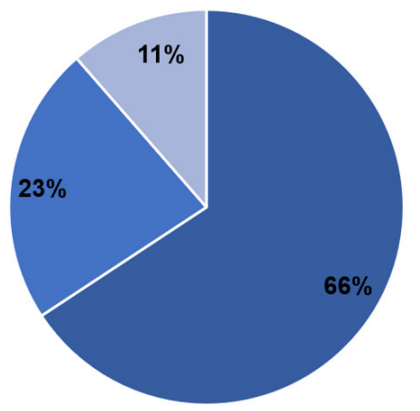

B

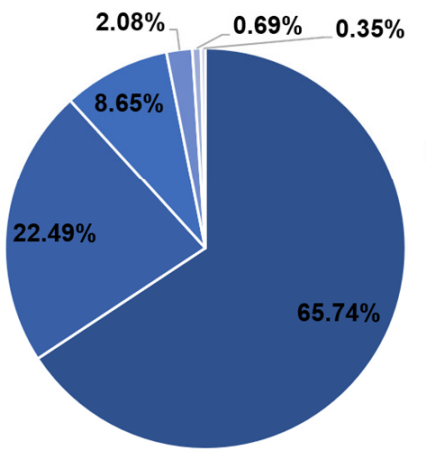

c
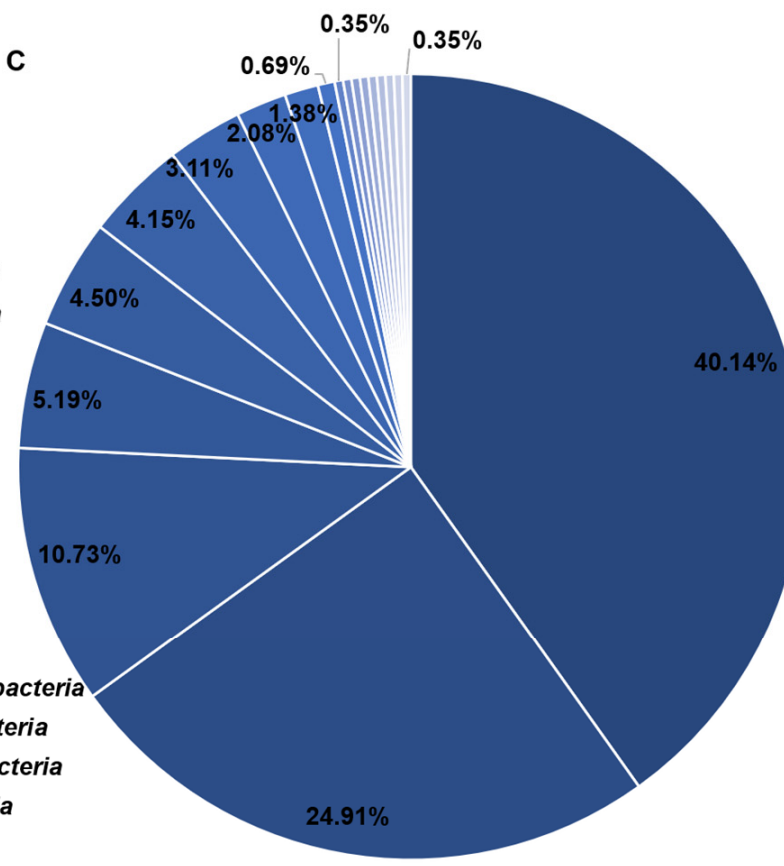

Genus

- Bacillus

- Staphylococcus

- Streptomyces

- Pantoea

- Brevibacterium

- Nocardiopsis

- Pseudomonas

- Achromobacter

- Corynebacterium

- Mesobacillus

- Brachybacterium

- Clavibacter

- Erwinia

Micrococcus

Mycolicibacterium

Novosphingobium

Patulibacter

Rhizobium

Rhodococcus

Figure 1. The percentage of endophytic bacterial isolates isolated from nine halophytic samples in the western Aral Sea at the phylum (A), class (B), and genus (C) level. 
About 26 isolates were isolated and purified from sample S1, belonging to two phyla, two classes, four orders, five families, and five genera. Thirty isolates were isolated and purified from sample S2, belonging to two phyla, two classes, two orders, three families, and three genera. Forty-six isolates were isolated and purified from sample S3, belonging to three phyla, three classes, three orders, four families, and four genera. Forty-nine isolates were isolated and purified from sample S4, belonging to two phyla, two classes, four orders, five families, and five genera. Sixteen isolates were isolated and purified from sample S5, belonging to three phyla, three classes, three orders, three families, and four genera. Sixteen isolates were isolated and purified from sample S6, belonging to two phyla, two classes, three orders, four families, and four genera. Forty-two isolates were isolated and purified from sample S7, belonging to three phyla, four classes, seven orders, seven families, and seven genera. Forty-six isolates were isolated and purified from sample S8, belonging to 3 phyla, 5 classes, 9 orders, 9 families, and 10 genera. Eighteen isolates were isolated and purified from sample S9, belonging to three phyla, three classes, five orders, five families, and five genera. The Shannon diversity indices from sample S1 to S9 figured by the $\mathrm{R}$ package vegan are $2.08,1.44,1.13,1.40,1.24,1.19,0.85,2.52$, and 1.61 respectively. The Simpson diversity indices from sample S1 to S9 figured by the R package vegan are $0.79,0.68,0.59,0.73,0.63,0.61,0.34,0.90$, and 0.75 respectively. The Richness indices from sample S1 to S9 counted by the R package vegan are 13.00, 7.00, 7.00, 5.00, 5.00, 5.00, 8.00, 16.00 , and 7.00 respectively. Pielou evenness indices from sample $S 1$ to $S 9$ calculated by the $\mathrm{R}$ package vegan are $0.81,0.74,0.58,0.87,0.77,0.74,0.41,0.91$, and 0.83 respectively. The statistics of isolation results clearly showed that the diversity and richness of S8 are the highest. The diversity of S7 is the lowest, while the richness of S5 and S6 are the lowest (Table 3).

Table 3. Diversity comparison of endophytic bacteria isolated from different samples.

\begin{tabular}{cccccccccc}
\hline Plant & S1 & S2 & S3 & S4 & S5 & S6 & S7 & S8 & S9 \\
\hline Phylum & 2 & 2 & 3 & 2 & 3 & 2 & 3 & 3 & 3 \\
Class & 2 & 2 & 3 & 2 & 3 & 2 & 4 & 5 & 3 \\
Order & 4 & 2 & 3 & 4 & 3 & 3 & 7 & 9 & 5 \\
Family & 5 & 3 & 4 & 5 & 3 & 4 & 7 & 9 & 5 \\
Genus & 5 & 3 & 4 & 5 & 4 & 4 & 7 & 10 & 5 \\
Isolates & 26 & 30 & 46 & 49 & 16 & 16 & 42 & 46 & 18 \\
Richness & 13.00 & 7.00 & 7.00 & 5.00 & 5.00 & 5.00 & 8.00 & 16.00 & 7.00 \\
Shannon & 2.08 & 1.44 & 1.13 & 1.40 & 1.24 & 1.19 & 0.85 & 2.52 & 1.61 \\
Simpson & 0.79 & 0.68 & 0.59 & 0.73 & 0.63 & 0.61 & 0.34 & 0.90 & 0.75 \\
Pielou & 0.81 & 0.74 & 0.58 & 0.87 & 0.77 & 0.74 & 0.41 & 0.91 & 0.83 \\
\hline
\end{tabular}

In the isolation experiments, we found no shared species between the nine samples. The exclusive species of sample S1 include seven species, identified as Bacillus licheniformis, Bacillus siamensis, Bacillus subtilis, Bacillus tequilensis, Micrococcus terreus, Streptomyces althioticus, and Streptomyces calvus respectively. The exclusive species of sample S2 include two species, identified as Bacillus pumilus and Streptomyces griseoviridis respectively. The exclusive species of sample S3 include two species, identified as Pseudomonas oryzihabitans and Streptomyces caeruleatus respectively. The exclusive species of sample S4 include three species, identified as Brevibacterium sediminis, Corynebacterium glyciniphilum, and Streptomyces puniceus respectively. The exclusive species of sample S5 include three species, identified as Mesobacillus campisalis, Nocardiopsis dassonvillei subsp. Albirubida, and Novosphingobium lindaniclasticum respectively. The exclusive species of sample S6 include two species, identified as Nocardiopsis trehalosi and Streptomyces setonii respectively. The exclusive species of sample S7 include four species, identified as Clavibacter michiganensis subsp. Phaseoli, Mycolicibacterium arabiense, Pseudomonas zhaodongensis, and Rhizobium yanglingense. The exclusive species of sample $\mathrm{S} 8$ include nine species, identified as Achromobacter deleyi, Achromobacter spanius, Bacillus atrophaeus, Bacillus kexueae, Brachybacterium faecium, Erwinia tasmaniensis, Patulibacter americanus, Pseudomonas atacamensis, and Rhodococcus sovatensis 
respectively. The exclusive species of sample S9 include one, identified as Bacillus badius (Figure 2). Therefore, there are some enormous differences in the endophytic bacteria community structure between the nine samples.

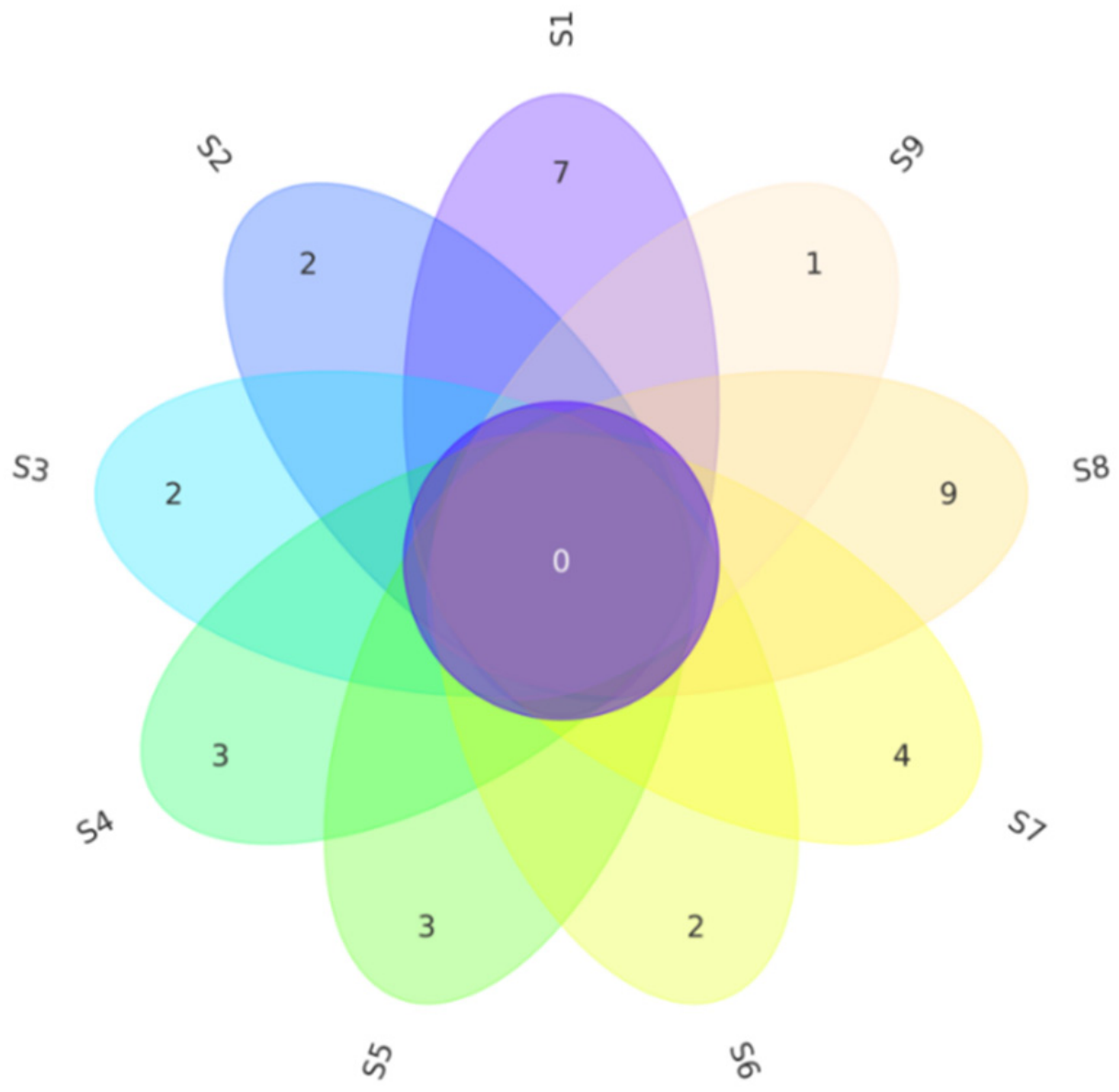

Figure 2. Flower diagram shows the difference of endophytic bacteria among different samples based on culture-dependent methods.

\subsection{Comparison of Isolation Effects between Different Media}

With the purpose of finding an appropriate culture medium for the isolation of endophytic bacteria associated with halophytes growing on the shore of the western Aral Sea Basin in Uzbekistan, we compared and analyzed the isolation effect of 12 different media. After comparison, it was found that the best medium for isolating endophytic bacteria related to halophytes from the western Aral Sea Basin is M7, which takes tryptone and soybean peptone as the carbon-nitrogen source. A certain number of endophytic bacteria were isolated from all nine halophyte samples in both M1 and M7 media. On the contrary, there are no endophytic bacteria isolated from nine halophyte samples using M4 and M8 media, which take L-asparagine and citric acid as the carbon-nitrogen source. Therefore, M4 and M8 media were totally unsuitable for isolating endophytic bacteria related to halophytes from the western Aral Sea (Figure 3). 


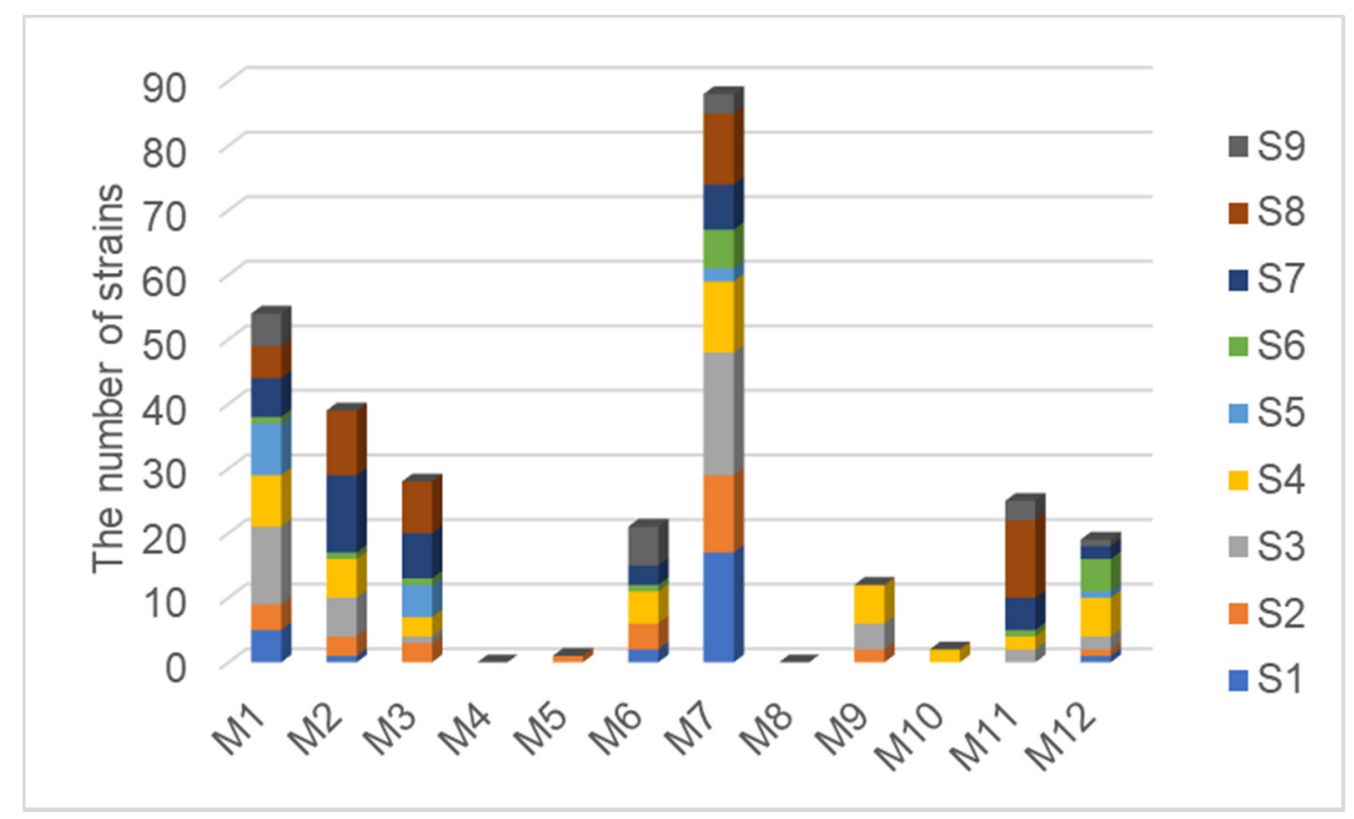

Figure 3. Comparison of endophytic bacteria isolation by different media.

\subsection{Comparison of the Isolated Effect of Endophytic Bacteria Isolated from Halophytes between Different Exposed Zones}

To understand and explore the isolation effect and the difference of community composition of endophytic bacterial isolates from dominant halophytes growing on the different bared zone, the Upset plot was drawn using the R package "UpSet R". (Figure 4). A total of 19 genera were detected across six exposed zones with one genus common to all exposed zones, which was identified as Bacillus. Ten genera of endophytic bacteria were isolated from the dominant halophytes of the ODZ group. The number of genera exclusive to the ODZ group was five, which were identified as Achromobacter, Brachybacterium, Erwinia, Patulibacter, and Rhodococcus respectively. Nine genera of endophytic bacteria were isolated from the dominant halophytes of the E1970S group. The number of genera exclusive to the exposed zone E1970S was three, which were identified as Clavibacter, Mycolicibacterium, and Rhizobium respectively. Four genera of endophytic bacteria were isolated from the dominant halophytes of the E1980S group. The number of genera exclusive to the exposed zone E1980S was two, which were identified as Mesobacillus and Novosphingobium respectively. Six genera of endophytic bacteria were isolated from the dominant halophytes of the E1990S group. The number of genera exclusive to the exposed zone E1990S was two, which were identified as Brevibacterium and Corynebacterium respectively. Five genera of endophytic bacteria were isolated from the dominant halophytes of the E2009S group. The number of genera exclusive to the exposed zone E2009S was 1, which was identified as Micrococcus. Three genera of endophytic bacteria were isolated from the dominant halophytes of the E2000S group. However, there was no one exclusive genus in exposed zone E2000S. The isolated numbers of endophytic bacteria from halophytes in different exposed zones were also displayed in Figure 4. It can be found that the isolated numbers of endophytic bacteria associated with halophytes from the western Aral Sea showed a decreasing trend with the shortening of exposure time. This may be because the shorter the exposure time of the lake bed, the worse the vegetation restoration and coverage so that the endophytic bacteria are less enriched in the plants during a limited time. 


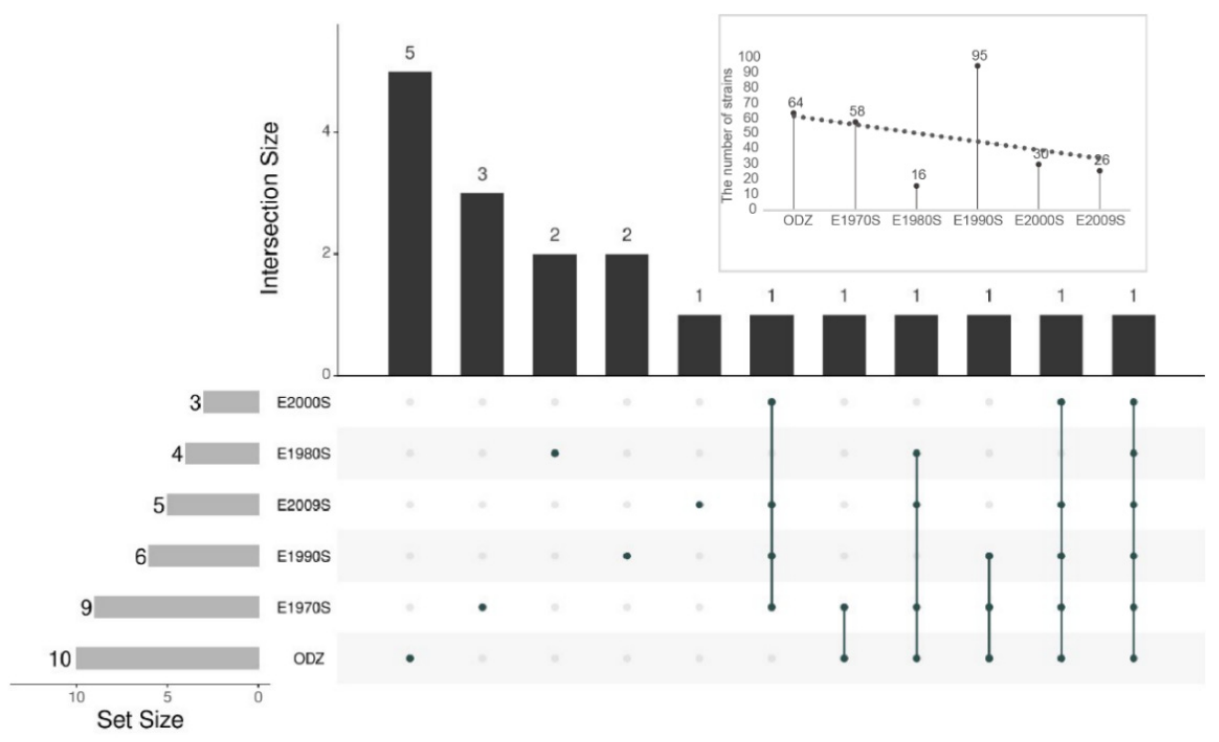

Figure 4. The Upset plot of endophytic bacteria from nine halophytes at the genus level.

\subsection{Production of Protease, Lipase, and Cellulose by Endophytic Bacterial Isolates}

In this experimental part, 42 different top-hit taxa were selected to test enzymeproducing capability. The results of enzyme-producing endophytic bacterial isolates were analyzed and visualized by Microsoft Excel 2019 (Figure 5). The screening results of protease-producing endophytic bacterial isolates indicated that $52 \%$ of the tested endophytic bacterial isolates showed negative, only one endophytic bacterial isolate S6-11 (size: $1382 \mathrm{bp}$ ) showed strong activity, which was identified as Nocardiopsis trehalosi (similarity: $99.78 \%$ ) (Figure 5A). Similarly, the screening results of lipase-producing endophytic bacterial isolates showed that half of the tested endophytic bacterial isolates showed negative, while only one endophytic bacterial isolate S4-30 (size: 1327 bp) showed strong activity, which was identified as Streptomyces puniceus (similarity: 100\%) (Figure 5B). Although the screening results of cellulose-producing endophytic bacterial isolates showed that $62 \%$ of the tested endophytic bacterial isolates showed negative, five endophytic bacterial isolates S1-21 (size: 1350 bp), S9-9 (size: 1408 bp), S1-24 (size: 1322 bp), S2-14 (size: 1320 bp), and S4-30 (size: $1327 \mathrm{bp}$ ) displayed strong activity, which were identified as Bacillus tequilensis (similarity: 99.85\%), Nocardiopsis synnemataformans (similarity: 98.50\%), Streptomyces calvus (similarity: 100\%), Streptomyces griseoviridis (similarity: 100\%), and Streptomyces puniceus (similarity: 100\%) respectively (Figure 5C). Based on the comparison of screening results, we found that six endophytic bacterial isolates have all the ability to produce these three tested enzymes (Supplementary Table S3).

A

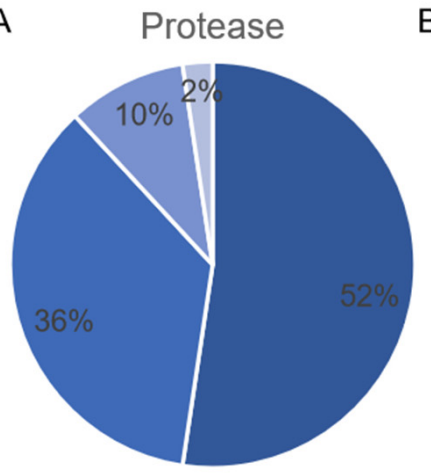

B

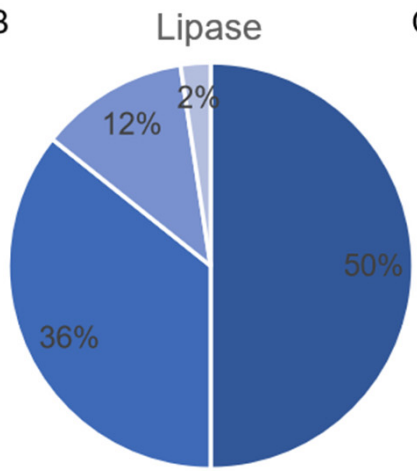

C

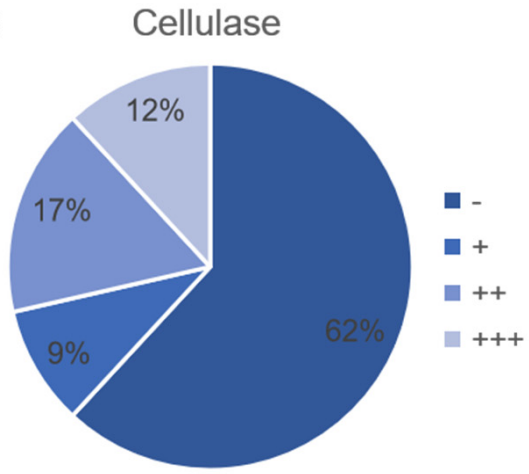

Figure 5. Screening results of endophytic bacteria isolates producing protease (A), lipase (B), and cellulose (C) (Notes: -: negative $(\mathrm{E}=1),+$ : weak $(1<\mathrm{E} \leq 2),++$ : moderate $(2<\mathrm{E} \leq 3),+++$ : strong $(\mathrm{E}>3))$. 


\subsection{Antifungal Activity of Endophytic Bacterial Isolates}

In this experimental part, the same 42 different top-hit taxa were also selected to test the antagonistic effect of apple canker (Valsa mali). The results showed that only eight endophytic bacterial isolates exhibited significant inhibition to the growth of Valsa mali (Figure 6). Nevertheless, the average inhibition rate of endophytic bacterial isolate S1-20 (size: 1352 bp), which was identified as Bacillus siamensis (similarity: 99.93\%), was the highest up to about $73.33 \%$, and compared with other isolates, it has a significant difference (LSD test, $p<0.05$ ) (Figure 6A). After that, we screened eight endophytic bacterial isolates with the ability to inhibit against Valsa mali to test the other three kinds of pathogenic fungi (Verticillium dahliae, Fusarium oxysporum, and Fusarium solani). Our findings showed that the only endophytic bacterial isolate that exhibited the inhibition effect on Fusarium oxysporum and Fusarium solani is S1-20. The average inhibition rates of the isolate S1-20 inhibiting Fusarium oxysporum and Fusarium solani were $68.14 \%$ and $51.21 \%$. We obtained four endophytic bacterial isolates: S1-20 (size: 1352 bp), S1-21 (size: 1350 bp), S8-2 (size: 1056 bp), and S8-19 (size: $1324 \mathrm{bp}$ ) with the ability to inhibit Verticillium dahliae via a screening experiment, which were identified as Bacillus siamensis (similarity: 99.93\%), Bacillus tequilensis (similarity: 99.85\%), Pantoea vagans (similarity: 99.43\%), and Achromobacter deleyi (similarity: $100 \%$ ) respectively. In addition, their average inhibition rates were $34.06 \%, 34.06 \%, 16.67 \%$, and $16.67 \%$ respectively (Supplementary Table S4). Figures $6 \mathrm{~B}$ and 7 are exhibitions of isolate S1-20, inhibiting four kinds of pathogenic fungi. Finally, we evaluated the difference in inhibition rates of endophytic bacterial isolate S1-20, suppressing four pathogenic fungi. It turns out that the endophytic bacterial isolate S1-20 presented the best inhibition effect and the highest inhibition rate on Valsa Mali, followed by Fusarium oxysporum, Fusarium solani, and Verticillium dahliae (Figure 8). The LSD test showed that the inhibition rates of isolate S1-20 against four kinds of pathogenic fungi were marked by different letters. Therefore, there were significant differences in the inhibition rates of isolate S1-20 against four kinds of pathogenic fungi.

A

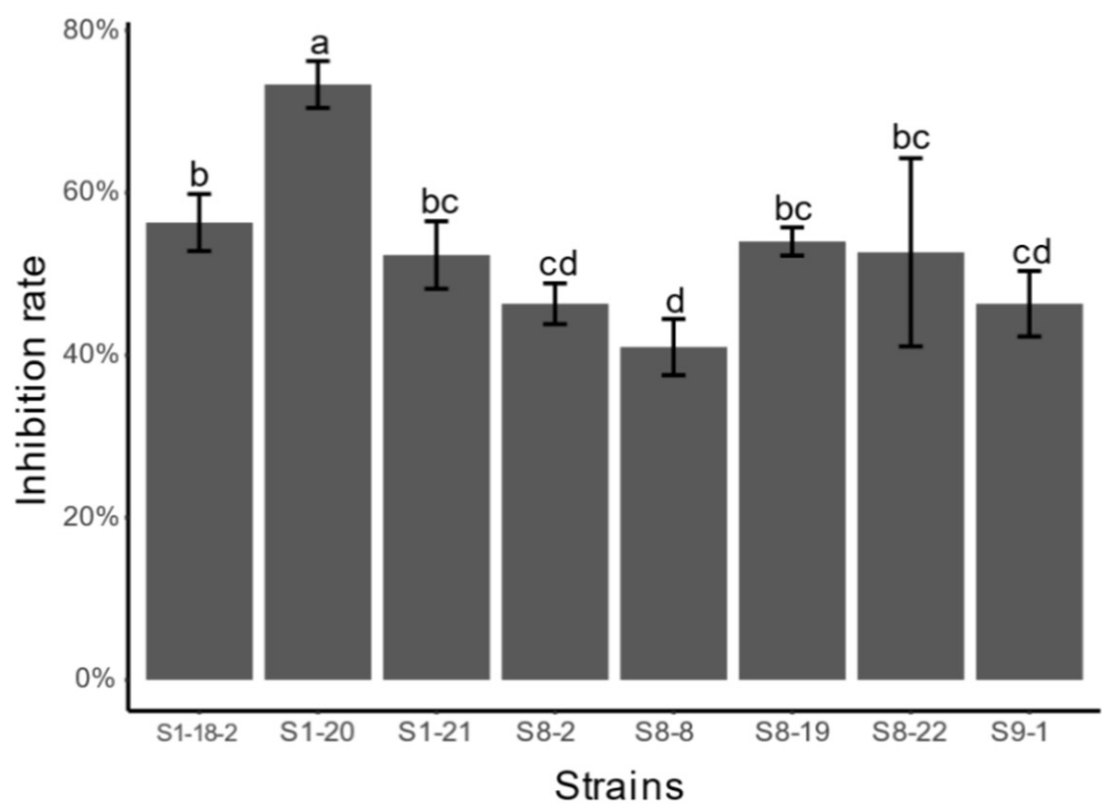

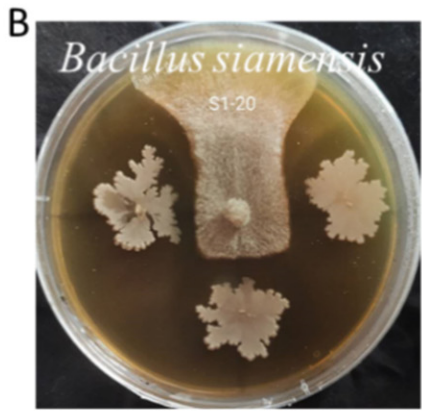

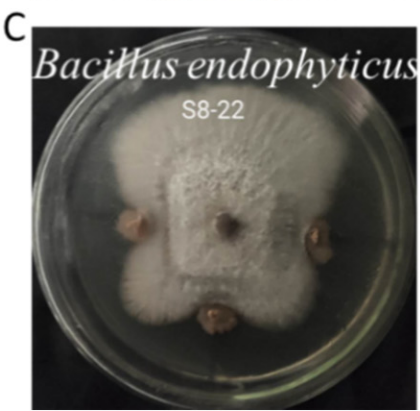

Figure 6. Screening results of endophytic bacterial isolates against pathogenic fungi of apple canker (Valsa mali), (A): bar chart of inhibition rate of endophytic bacteria against Valsa mali, (B): antagonistic effect picture of isolate S1-20, (C): antagonistic effect picture of isolate S8-22. The LSD test was used to check whether there was a significant difference in the inhibition rate among the different endophytic bacterial isolates. There were significant differences in the inhibition rate of endophytic bacterial isolates labeled with different letters. There was no significant difference in the inhibition rate between endophytic bacterial isolates labeled with repeated letters. 
A

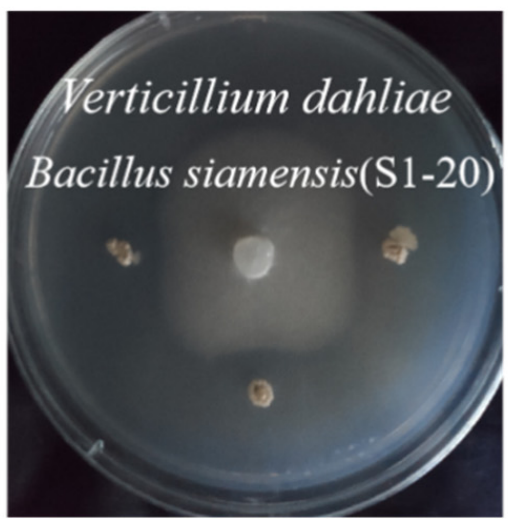

$\mathrm{B}$

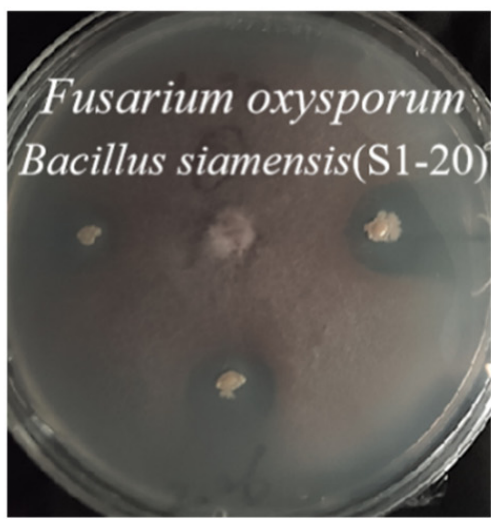

C

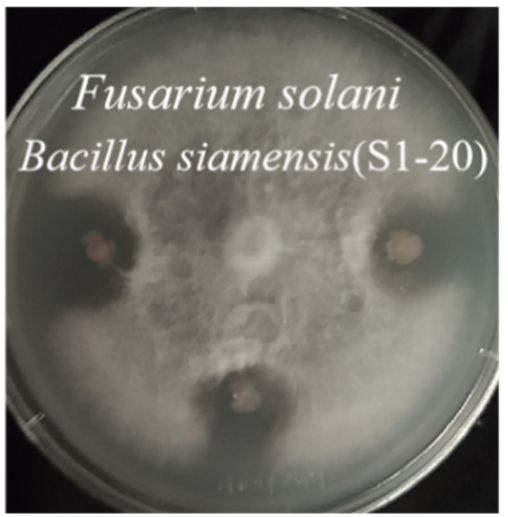

Figure 7. Exhibition of antagonistic effects of endophytic bacterial isolate S1-20 against pathogenic fungi ((A): Verticillium dahliae, (B): Fusarium oxysporum, and (C): Fusarium solani).

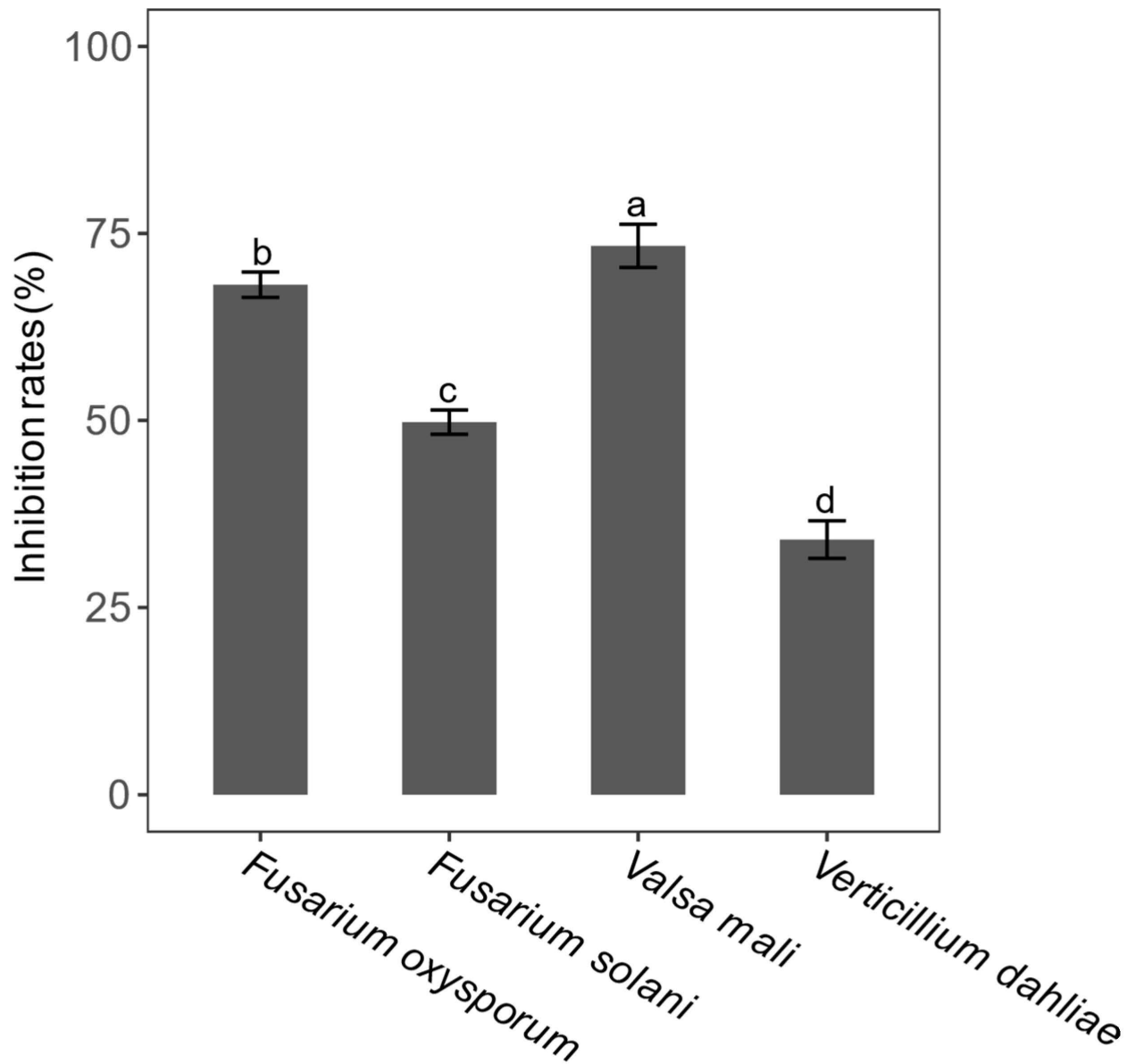

Figure 8. Inhibition rates of endophytic bacteria isolate S1-20 against four different pathogenic fungi (Valsa mali, Verticillium dahliae, Fusarium oxysporum, and Fusarium solani). The LSD test was used to detect whether there were significant differences in the inhibition rates of endophytic bacteria isolate S1-20 against four kinds of pathogenic fungi. There were significant differences in the inhibition rate of endophytic bacterial isolates labeled with different letters. 


\section{Discussion}

4.1. Cultivable Endophytic Bacterial Community Composition Associated with the Halophytes Growing on the Shore in the Western Aral Sea Basin

Based on the field investigation of vegetation restoration in the degraded zone of the Western Aral Sea, we found that the species and distribution of plants in the degraded zone of different lakes are quite different (Supplementary Table S1). In this study, based on the culture-dependent method, 289 endophytic bacterial isolates affiliated to 3 phyla, 6 classes, 14 orders, 17 families, and 19 genera were isolated from nine halophytic samples of six dominant halophytes growing on the shore of the western Aral Sea of Uzbekistan. The phylum Firmicutes accounted for $66 \%$ of the total number of isolates, followed by Actinobacteria $23 \%$, and Proteobacteria $11 \%$ (Figure 1A). The predominant genera of endophytic bacteria associated with halophyte from the western Aral Sea were Bacillus, Staphylococcus, and Streptomyces, accounting for $38.5 \%, 24.7 \%$, and $12.5 \%$ of the total number of isolates respectively (Figure 1C). Wang et al. investigated the endophytic bacteria of four Chenopodiaceae halophytes (including Borszczowia aralocaspica Bge., Salicornia europaea L., Salsola affinis C. A. Mey, and Anabasis elatior (C. A. Mey.) Schischk) in Xinjiang by using two isolation methods and 10 media and found that Streptomyces and Bacillus were the main dominant groups [31]. When studying the developmental peculiarities of Chenopodium quinoa, Pitzschke demonstrated that $100 \%$ of quinoa seeds are inhabited by diverse members of the genus Bacillus, which are motile, vertical inheritance, and reside in all seedling organs [32]. In our findings, we isolated 32 endophytic bacterial isolates belonging to the genus Bacillus from Chenopodium album L., which were identified as six different top-hit taxa (Supplementary Table S2). The richness of S5 and S6 (Haloxylon ammodendron (C. A. Mey.) Bunge) was the lowest in our analysis. According to the search result from PubMed, nowadays, only two new endophytic bacterial species related to Haloxylon ammodendron have been published $[33,34]$. The diversity of S7 was the lowest in our results because only Bacillus swezeyi was isolated. Unlike our results, in 2020, Zhang et al. investigated the microbial community composition of Alhagi sparsifolia applied 16S rRNA gene amplicon sequencing and found that the dominant class belongs to Gammaproteobacteria with relative abundances of 94.8 to $98.2 \%$ in all root endosphere samples [35]. Anyway, the endophytic bacteria associated with halophytes have the characteristics of diversity, universality, and specificity [36]. Consequently, in the future, it is necessary to deeply explore endophytic bacterial diversity related to halophytes growing on the shore of the western Aral Sea by combining the culture-dependent method with high throughput sequencing.

\subsection{The Exploration on the Best Isolation Protocol of Halophyte Endophytic Bacteria}

In this paper, the isolation of endophytic bacterial isolates from halophytes was performed using 12 kinds of different media through the spread plate method and streak plate method. According to comparison, it was found that the M7 medium taking yeast extract and tryptone as the carbon source was more effective in the isolation of endophytic bacteria associated with halophytes growing on exposed zones in the western Aral Sea (Figure 3). After Huang et al. investigated root-associated bacteria from Platycodon grandiflorum, a medicinal plant commonly growing in East Asia, they found only a few bacterial lineages were found in all cultural media, and most were only enriched and obtained on a single culture medium [37]. Our findings, as well as previous studies, have all shown that multiple media have a greater possibility of obtaining a broader range of bacterial lines. This is an extremely valuable guide to choose multiple media of different nutritional components for the isolation of endophytic bacteria. 


\subsection{The Screening of the Endophytic Bacterial Isolates Producing Enzyme and Inhibiting Pathogenic Fungi}

Biological control of plant pathogens using endophytic bacteria is an efficient method and a friendly environment way for inhibiting plant diseases [38]. Endophytic bacteria associated with halophytes are rich sources of secondary metabolites with antipathogenic fungi activity, and they spend their whole life cycle living in plant tissues without inducing any infections or diseases [39]. In our study, we analyzed the enzymeproducing activity and the antimicrobial activity of a diverse collection of endophytic bacteria isolated from halophytes, to determine which isolate was provided with the strong enzyme-producing activities and antagonistic activities repressing pathogens. The screening for antagonistic activity was conducted by co-cultivating the endophytic bacteria associated with halophytes with common phytopathogenic fungi of the potato wilt (Fusarium oxysporum and Fusarium solani), verticillium wilt of cotton (Verticillium dahliae), and apple canker (Valsa mali) in vitro [40-42]. In our assays, several endophytic bacteria displayed antagonistic effects, which were identified as Bacillus subtilis, Bacillus siamensis, Bacillus tequilensis, Pantoea vagans, Bacillus atrophaeus, Bacillus kexueae, Achromobacter deleyi, and Nocardiopsis dassonvillei subsp. dassonvillei respectively (Supplementary Tables S2 and S3). According to previous research results, it is not difficult to find that the genus Bacillus was the dominant genus, with high antimicrobial activity against nearly all pathogenetic fungi, which is consistent with our research results [43]. In our screening findings, only one endophytic bacterial isolate, S1-20, representing Bacillus siamensis, possessed the ability to resist four tested kinds of pathogenic fungi and exhibited moderate-high inhibition rates. Besides, we also detected that isolate S1-20 had both protease-producing and cellulose-producing activities (Supplementary Table S3). Bacillus siamensis was, for the first time, isolated from salted crab in Thailand and phenotypic and chemotaxonomic characteristics, including phylogenetic analyses, showed that the novel isolate was a member of the genus Bacillus [44]. As early as 2018, Xu et al. demonstrated the broad-spectrum antibacterial activity of Bacillus siamensis, identified cyclic lipopeptides from Bacillus siamensis for the first time, and used them to suppress the growth of various multidrug-resistant bacterial pathogens [45]. Based on our research and previous studies, we can conclude that Bacillus siamensis has extensive resistance to pathogenic bacteria and fungi. For this reason, Bacillus siamensis has a broad development and application prospect in agricultural production. Shurigin et al. [46] reported that antifungal activity of endophytic bacteria such as Paenibacillus, Stenotrophomonas, Pseudomonas, Brevibacterium, and Pantoea inhibited phytopathogenic fungi Rhizoctonia solani, Fusarium culmorum, and Fusarium solani. Certainly, a further study is necessary for the pot as well as field experiments to verify the antagonistic effect of the isolate S1-20 (Bacillus siamensis).

\section{Conclusions}

A total of 289 endophytic bacteria belonging to the phyla Firmicutes, Actinobacteria, and Proteobacteria were isolated from nine halophytes growing on the shore of the western Aral Sea in Uzbekistan. The predominant genera were Bacillus, Staphylococcus, and Streptomyces in endophytic bacterial isolates isolated from nine halophytes. The M7 medium, which took tryptone and soybean peptone as the carbon-nitrogen source, was the best medium for isolating halophyte-related endophyte bacteria in the western Aral Sea region. The isolated number of endophytic bacteria associated with halophytes growing on the western Aral Sea showed a declining trend along with the shortening of exposure time. We acquired one endophytic bacterial isolate with the strong ability to produce protease, one endophytic bacterial isolate with the strong ability to produce lipase, and five endophytic bacterial isolates with the strong ability to produce cellulose. Simultaneously, we also found that six endophyte bacterial isolates have the full capability of producing these three tested enzymes. Eight endophytic bacterial isolates capable of significantly inhibiting the growth of Valsa mail were obtained. Moreover, one single isolate S1-20 (Bacillus siamensis) also has all the inhibitory effects on Verticillium dahliae, Fusarium oxysporum, and Fusarium solani. 
Our results suggest that halophytes are sources for the selection of microbes that can protect plant growth under adverse conditions. Besides, further research is needed for the glasshouse as well as field experiments to verify the biological control efficacy of selected endophytic bacteria.

Supplementary Materials: The following are available online at https: / www.mdpi.com/article/ 10.3390/microorganisms9071448/s1. Table S1: Supplementary Table S1.xlsx, Table S2: Supplementary Table S2.xlsx, Table S3: Supplementary Table S3.xlsx, Table S4: Supplementary Table S1.xlsx.

Author Contributions: Conceptualization, L.G. and L.L.; methodology, J.M. and L.G.; formal analysis, L.G., J.M. and Y.L.; investigation, O.A.A.M. and Y.H.; resources, L.L. and J.M.; data curation, H.J.; writing-original draft preparation, L.G.; writing—review and editing, O.A.A.M., D.E. and J.M.; visualization, D.E.; supervision, W.L. and L.L.; project administration W.L. and L.L.; funding acquisition, W.L. and L.L. All authors have read and agreed to the published version of the manuscript.

Funding: This research was supported by Xinjiang Uygur Autonomous Region regional coordinated innovation project (Shanghai cooperation organization science and technology partnership program) (No. 2020E01047), National Natural Science Foundation of China (Nos: 32061143043, 32050410306 and 32000084).

Data Availability Statement: Raw sequence data reported in this paper have been deposited in the GenBank in the NCBI under accession number MW664036-MW664324.

Acknowledgments: The authors acknowledge the anonymous reviewers for their constructive comments on the manuscript.

Conflicts of Interest: The authors declare no conflict of interest.

\section{References}

1. Austin, P.; Mackay, A.; Palagushkina, O.; Leng, M. A High-Resolution Diatom-Inferred Palaeoconductivity and Lake Level Record of the Aral Sea for the Last 1600 Yr. Quat. Res. 2007, 3, 383-393. [CrossRef]

2. Herschy, R.W. Aral Seaaral Sea. In Encyclopedia of Hydrology and Lakes; Springer: Dordrecht, The Netherlands, $1998 ;$ p. 70.

3. Varotsos, C.A.; Krapivin, V.F.; Mkrtchyan, F.A. On the Recovery of the Water Balance. Water Air Soil Pollut. 2020, 4, 170. [CrossRef]

4. Shurigin, V.; Egamberdieva, D.; Li, L.; Davranov, K.; Panosyan, H.; Birkeland, N.; Wirth, S.; Bellingrath-Kimura, S.D. Endophytic Bacteria Associated with Halophyte Seidlitzia Rosmarinus Ehrenb. Ex Boiss. From Saline Soil of Uzbekistan and Their Plant Beneficial Traits. J. Arid Land 2020, 5, 730-740. [CrossRef]

5. Agrios, G.N. Plant Diseases Caused by Fungi. In Plant Pathology, 2nd ed.; Agrios, G.N., Ed.; Academic Press: Cambridge, MA, USA, 1978; pp. 172-434.

6. Widiantini, F.; Qadryani, M.R.; Hartati, F.; Yulia, E. Antifungal Potency of Secondary Metabolites Produced by Endophytic Bacteria against Pathogenic Fungi Pyricularia Oryzae Cav. J. Perlindungan Tanam. Indones. 2019, 2, 185. [CrossRef]

7. Triky-Dotan, S.; Yermiyahu, U.; Katan, J.; Gamliel, A. Development of Crown and Root Rot Disease of Tomato under Irrigation with Saline Water. Phytopathology 2005, 12, 1438-1444. [CrossRef]

8. Egamberdieva, D.; Kucharova, Z.; Davranov, K.; Berg, G.; Makarova, N.; Azarova, T.; Chebotar, V.; Tikhonovich, I.; Kamilova, F.; Validov, S.Z.; et al. Bacteria Able to Control Foot and Root Rot and to Promote Growth of Cucumber in Salinated Soils. Biol. Fertil. Soils 2011, 2, 197-205. [CrossRef]

9. Egamberdieva, D.; Davranov, K.; Wirth, S.; Hashem, A.; Abd_Allah, E.F. Impact of Soil Salinity on the Plant-Growth-Promoting and Biological Control Abilities of Root Associated Bacteria. Saudi J. Biol. Sci. 2017, 7, 1601-1608. [CrossRef]

10. Ludueña, L.M.; Taurian, T.; Tonelli, M.L.; Angelini, J.G.; Anzuay, M.S.; Valetti, L.; Muñoz, V.; Fabra, A.I. Biocontrol Bacterial Communities Associated with Diseased Peanut (Arachis Hypogaea L.) Plants. Eur. J. Soil Biol. 2012, 48-55. [CrossRef]

11. Lugtenberg, B.; Kamilova, F. Plant-Growth-Promoting Rhizobacteria. Annu. Rev. Microbiol. 2009, 541-556. [CrossRef] [PubMed]

12. Cho, S.T.; Chang, H.H.; Egamberdieva, D.; Kamilova, F.; Lugtenberg, B.; Kuo, C.H. Genome Analysis of Pseudomonas Fluorescens Pcl1751: A Rhizobacterium That Controls Root Diseases and Alleviates Salt Stress for Its Plant Host. PLoS ONE 2015, 10, e0140231. [CrossRef] [PubMed]

13. Etesami, H.; Beattie, G.A. Mining Halophytes for Plant Growth-Promoting Halotolerant Bacteria to Enhance the Salinity Tolerance of Non-Halophytic Crops. Front. Microbiol. 2018, 148. [CrossRef] [PubMed]

14. Santoyo, G.; Moreno-Hagelsieb, G.; del Carmen Orozco-Mosqueda, M.; Glick, B.R. Plant Growth-Promoting Bacterial Endophytes. Microbiol. Res. 2016, 92-99. [CrossRef] [PubMed]

15. Afzal, M.; Khan, Q.M.; Sessitsch, A. Endophytic Bacteria: Prospects and Applications for the Phytoremediation of Organic Pollutants. Chemosphere 2014, 232-242. [CrossRef] [PubMed]

16. Fan, D.; Subramanian, S.; Smith, D.L. Plant Endophytes Promote Growth and Alleviate Salt Stress in Arabidopsis Thaliana. Sci. Rep. 2020, 1, 12740. [CrossRef] 
17. Martinez-Klimova, E.; Rodríguez-Peña, K.; Sánchez, S. Endophytes as Sources of Antibiotics. Biochem. Pharmacol. $2017,1-17$. [CrossRef]

18. Zicca, S.; De-Bellis, P.; Masiello, M.; Saponari, M.; Saldarelli, P.; Boscia, D.; Sisto, A. Antagonistic Activity of Olive Endophytic Bacteria and of Bacillus Spp. Strains against Xylella Fastidiosa. Microbiol. Res. 2020, 126467. [CrossRef]

19. Vurukonda, S.; Giovanardi, D.; Stefani, E. Plant Growth Promoting and Biocontrol Activity of Streptomyces spp. As Endophytes. Int. J. Mol. Sci. 2018, 4, 952. [CrossRef] [PubMed]

20. You, J.M.; Xiong, K.; Mu, S.; Guo, J.; Guo, X.L.; Duan, Y.Y.; Li, J.; Cao, F.; Zou, Z.C.; Tan, H. Identification of Endophytic Bacteria Bzjn1 and Research on Biological Control of Root Rot of Atractylodes Macrocephala. Zhongguo Zhong Yao Za Zhi 2018, 3, 478-483. [CrossRef]

21. Wang, S.S.; Liu, J.M.; Sun, J.; Sun, Y.F.; Liu, J.N.; Jia, N.; Fan, B.; Dai, X.F. Diversity of Culture-Independent Bacteria and Antimicrobial Activity of Culturable Endophytic Bacteria Isolated from Different Dendrobium Stems. Sci. Rep. 2019, 1, 10389. [CrossRef]

22. Bibi, F.; Naseer, M.I.; Hassan, A.M.; Yasir, M.; Al-Ghamdi, A.A.K.; Azhar, E.I. Diversity and Antagonistic Potential of Bacteria Isolated from Marine Grass Halodule Uninervis. 3 Biotech 2018, 1, 48. [CrossRef] [PubMed]

23. Jiang, H.C.; Huang, J.R.; Li, L.; Huang, L.Q.; Manzoor, M.; Yang, J.; Wu, G.; Sun, X.X.; Wang, B.C.; Egamberdieva, D.; et al. Onshore Soil Microbes and Endophytes Respond Differently to Geochemical and Mineralogical Changes in the Aral Sea. Sci. Total Environ. 2021, 142675. [CrossRef]

24. Liu, Y.H.; Guo, J.W.; Li, L.; Asem, M.; Zhang, Y.G.; OAMohamad Salam, N.; Li, W.J. Erratum To: Endophytic Bacteria Associated with Endangered Plant Ferula Sinkiangensis K. M. Shen in an Arid Land: Diversity and Plant Growth-Promoting Traits. J. Arid Land 2017, 4, 635. [CrossRef]

25. Xu, W.; Wang, F.; Zhang, M.; Ou, T.; Wang, R.; Strobel, G.; Xiang, Z.; Zhou, Z.; Xie, J. Diversity of Cultivable Endophytic Bacteria in Mulberry and Their Potential for Antimicrobial and Plant Growth-Promoting Activities. Microbiol. Res. 2019, 126328. [CrossRef] [PubMed]

26. Rohban RAMohammad, A.; Ventosa, A. Screening and Isolation of Halophilic Bacteria Producing Extracellular Hydrolyses from Howz Soltan Lake, Iran. J. Ind. Microbiol. Biotechnol. 2009, 3, 333-340. [CrossRef] [PubMed]

27. Bao, W.; Jiang, J.; Zhou, Y.; Wu, Y.; Leung, F.C. Screening and Genomic Analysis of a Lignocellulose Degrading Bacterium. Acta Microbiol. Sin. 2016, 5, 765-777.

28. Mesa, J.; Mateos-Naranjo, E.; Caviedes, M.A.; Redondo-Gómez, S.; Pajuelo, E.; Rodríguez-LlorenteIgnacio, D. Endophytic Cultivable Bacteria of the Metal Bioaccumulator Spartina Maritima Improve Plant Growth but Not Metal Uptake in Polluted Marshes Soils. Front. Microbiol. 2015, 1450. [CrossRef] [PubMed]

29. Liu, Y.H.; Guo, J.W.; Salam, N.; Li, L.; Zhang, Y.G.; Han, J.; Mohamad, O.A.; Li, W.J. Culturable Endophytic Bacteria Associated with Medicinal Plant Ferula Songorica: Molecular Phylogeny, Distribution and Screening for Industrially Important Traits. 3 Biotech 2016, 2, 209. [CrossRef]

30. Mohamad, O.A.A.; Li, L.; Ma, J.B.; Hatab, S.; Xu, L.; Guo, J.W.; Rasulov, B.A.; Liu, Y.H.; Hedlund, B.P.; Li, W.J. Evaluation of the Antimicrobial Activity of Endophytic Bacterial Populations from Chinese Traditional Medicinal Plant Licorice and Characterization of the Bioactive Secondary Metabolites Produced by Bacillus Atrophaeus against Verticillium Dahliae. Front. Microbiol. 2018, 9, 924. [CrossRef] [PubMed]

31. Wang, H.F. Study on Biodiversity of Endophytic Bacteria Isolated from Four Chenopodiaceae Halophytes in Xinjiang and Evaluation of Their Growth Promoting Function and Salt-Tolerance Ability. Ph.D. Thesis, University of Chinese Academy of Sciences, Beijing, China, 2015.

32. Pitzschke, A. Developmental Peculiarities and Seed-Borne Endophytes in Quinoa: Omnipresent, Robust Bacilli Contribute to Plant Fitness. Front. Microbiol. 2016, 2. [CrossRef] [PubMed]

33. Liu, L.; Hui, N.; Liang, L.X.; Zhang, X.X.; Li, L.B.; Sun, Q.W. Sphingobacterium Haloxyli Sp. Nov., an Endophytic Bacterium Isolated from Haloxylon Ammodendron Stems in Kumtag Desert. Int. J. Syst. Evol. Microbiol. 2018, 10, 3279-3284. [CrossRef] [PubMed]

34. Liu, L.; Li, L.; Song, Z.; Wang, S.; Zhang, J.; Zhang, X.; Sun, Q. Parapedobacter Deserti Sp. Nov., an Endophytic Bacterium Isolated from Haloxylon Ammodendron Stems. Int. J. Syst. Evol. Microbiol. 2017, 7, 2148-2152. [CrossRef] [PubMed]

35. Zhang, L.; Zhang, W.; Li, Q.; Cui, R.; Wang, Z.; Wang, Y.; Zhang, Y.Z.; Ding, W.; Shen, X. Deciphering the Root Endosphere Microbiome of the Desert Plant Alhagi Sparsifolia for Drought Resistance-Promoting Bacteria. Appl. Environ. Microbiol. 2020, 11. [CrossRef] [PubMed]

36. Zhao, S.; Zhou, N.; Zhao, Z.; Zhang, K.; Wu, G.; Tian, C.Y. Estimation of Endophytic Bacterial Diversity in Root of Halophytes in Northern Xinjiang by High Throughput Sequencing. Acta Microbiol. Sin. 2016, 10, 1583-1594.

37. Huang, C.M.; Chen, W.C.; Lin, S.H.; Wang, Y.N.; Shen, F.T. Exploration of Root-Associated Bacteria from the Medicinal Plant Platycodon Grandiflorum. Microbes Environ. 2019, 4, 413-420. [CrossRef]

38. Cumagun, C.; Joseph, R. Chapter 39-Advances in Formulation of Trichoderma for Biocontrol. In Biotechnology and Biology of Trichoderma; Gupta, V.K., Schmoll, M., Herrera-Estrella, A., Upadhyay, R.S., Druzhinina, I., Tuohy, M.G., Eds.; Elsevier: Amsterdam, The Netherlands, 2014; pp. 527-531.

39. Saikkonen, K.; Wäli, P.; Helander, M.; Faeth, S.H. Evolution of Endophyte-Plant Symbioses. Trends Plant Sci. 2004, 6, 275-280. [CrossRef] 
40. Chen, H.; Xue, Y.F.; Meng, M.L.; Ma, Z.W.; Liu, Z.H.; Hu, J. Pathogen Identification and Biological Characteristics of Potato Wilt in Inner Mongolia. Chin. Potato J. 2016, 4, 226-234. [CrossRef]

41. Wang, J.Y.; Cai, Y.; Gou, J.Y.; Mao, Y.B.; Xu, Y.H.; Jiang, W.H.; Chen, X.Y. Vdnep, an Elicitor from Verticillium Dahliae, Induces Cotton Plant Wilting. Appl. Environ. Microbiol. 2004, 8, 4989-4995. [CrossRef]

42. Xu, M.; Gao, X.; Chen, J.; Yin, Z.; Feng, H.; Huang, L. The Feruloyl Esterase Genes Are Required for Full Pathogenicity of the Apple Tree Canker Pathogen Valsa Mali. Mol. Plant Pathol. 2018, 6, 1353-1363. [CrossRef] [PubMed]

43. Shafi, J.; Tian, H.; Ji, M.S. Bacillus Species as Versatile Weapons for Plant Pathogens: A Review. Biotechnol. Biotechnol. Equip. 2017, 3, 446-459. [CrossRef]

44. Sumpavapol, P.; Tongyonk, L.; Tanasupawat, S.; Chokesajjawatee, N.; Luxananil, P.; Visessanguan, W. Bacillus Siamensis Sp. Nov., Isolated from Salted Crab (Poo-Khem) in Thailand. Int. J. Syst. Evol. Microbiol. 2010, 10, 2364-2370. [CrossRef] [PubMed]

45. Xu, B.H.; Ye, Z.W.; Zheng, Q.W.; Wei, T.; Lin, J.F.; Guo, L.Q. Isolation and Characterization of Cyclic Lipopeptides with Broad-Spectrum Antimicrobial Activity from Bacillus Siamensis Jfl15. 3 Biotech 2018, 10, 444. [CrossRef] [PubMed]

46. Egamberdieva, D.; Shurigin VAlaylar, B.; Wirth, S.; Kimura, S.K.B. Bacterial endophytes from horseradish (Armoracia rusticana) with antimicrobial efficacy against pathogens. Plant Soil Environ. 2020, 66, 309-316. [CrossRef] 